\title{
From domestic water to agricultural water: how do donors contribute to the water crises in the occupied Palestinian territories?
}

\author{
Klervi FUSTEC \\ ${ }^{I}$ Associated researcher UMR ART-Dev - ATER University of French Polynesia B.P. 6570 - 98702 Faa'a - Tahiti - Polynésie française \\ klervi.fustec@gmail.com
}

\begin{abstract}
This article studies the water crises in the Occupied Palestinian Territories (OPT). The Israeli-Palestinian conflict as well as the water issues are generally described as an issue between two entities: the Israeli Authorities and the Palestinian Authorities. This is an oversimplification, other actors play a key role. This article focuses on donors' policies about water. The Oslo Agreements are one of the first factor influencing water issues in the OPT. This study demonstrates that donors associate the respect of the Oslo Agreements as the basis for peace and that they focus mainly on the process of Palestinian state-building and on urban water. We show that this framework does not take into account rural water and community-based management. For a few years donors seem to orient their projects toward rural areas and agriculture. In their discourses, donors also link this new interest to the solution of the conflict. Water is depicted as a technical issue. Nevertheless, this article demonstrates that, in this context, donors' representations of water and land are very specific. Water and land are highly political issues. Donors favor irrigated and export agriculture whereas rain-fed agriculture and small exploitations remain the majority. They favor some territories and some social groups to build a specific bio-physical and socio-political reality. Finally, this participates to the construction of a governmental entity "above the ground". All these processes may predict important changes of social organizations and water resources.
\end{abstract}

Key-words: Domestic water, agricultural water, Occupied Palestinian Territories, donors, state-building, power relations, urban and rural territories.

\section{De l'eau urbaine à l'eau rurale : comment les bailleurs de fonds participent-ils aux crises de l'eau dans les Territoires palestiniens occupés ?}

\begin{abstract}
RÉSUMÉ. - Cet article analyse les "crises de l'eau" dans les Territoires palestiniens occupés. Le conflit israélo-palestinien est souvent décrit comme une problématique concernant les autorités israéliennes et les autorités palestiniennes. Il s'agit d'une simplification, d'autres acteurs jouent un rôle capital et notamment les bailleurs de fonds. Les accords d'Oslo constituent le premier cadrage des problématiques liées à l'eau. Cette recherche montre que les bailleurs de fonds associent le respect de ces accords à la construction de la paix, qu'ils se focalisent majoritairement sur les processus de construction étatique palestinien et sur l'eau urbaine. Nous montrons que ce cadre ne prend pas en compte l'eau rurale et la gestion communautaire des ressources. Depuis quelques années, les bailleurs de fonds semblent orienter leurs projets vers les zones rurales et l'agriculture. Dans leurs discours, ils lient ces nouvelles politiques à la résolution du conflit. L'eau est décrite comme une question technique. Néanmoins, cet article démontre que, dans ce contexte, les représentations des bailleurs de fonds de l'eau et du territoire sont spécifiques et que ces enjeux sont intrinsèquement politiques. Les bailleurs de fonds, favorisent l'agriculture irriguée et destinée à l'exportation alors que les petites exploitations et l'agriculture pluviale restent majoritaires. Ils favorisent certains territoires et certains groupes sociaux et construisent une réalisé bio-physique et socio-politique particulière. Au final, cela participe à la construction d'une "entité gouvernementale hors-sol". Ces processus prédisent peut-être des changements importants concernent les organisations sociales comme les ressources en eau.
\end{abstract}

Mots-clés : Eau urbaine, eau rurale, Territoires Palestiniens Occupés, bailleurs de fonds, construction étatique, relations de pouvoir, territoires urbains et ruraux.

\section{INTRODUCTION}

Generally speaking, the Israeli-Palestinian conflict is described as a conflict between two entities. This is clearly an oversimplification [Trottier, 2012a]. Water issues should be understood in their complexity which means integrating supra and sub national actors and processes. In this context, this article will focus on donors' intervention. A major factor influencing both the socio-political and the water situation are the Oslo Agreements. What is important here is that these agreements establish the Palestinian Authority (PA) and its relations with Israel, they divide the West Bank (WB) into three areas and they assign quantities of water to each part. Area A is under the control of the PA, Area B is under joint Israeli and Palestinian control and Area $C$ is under the control of the Israeli Authorities. If we summarize, Area A correspond to the cities, Area B to the villages and Area C to the rural areas, the Jordan Valley, the colonies, the Israeli 
military installations and the natural reserves. Only $18 \%$ of the territory is under the control of the PA, Area B represents about $21 \%$ of the territory and Area C $61 \%^{1}$ (Map 12).

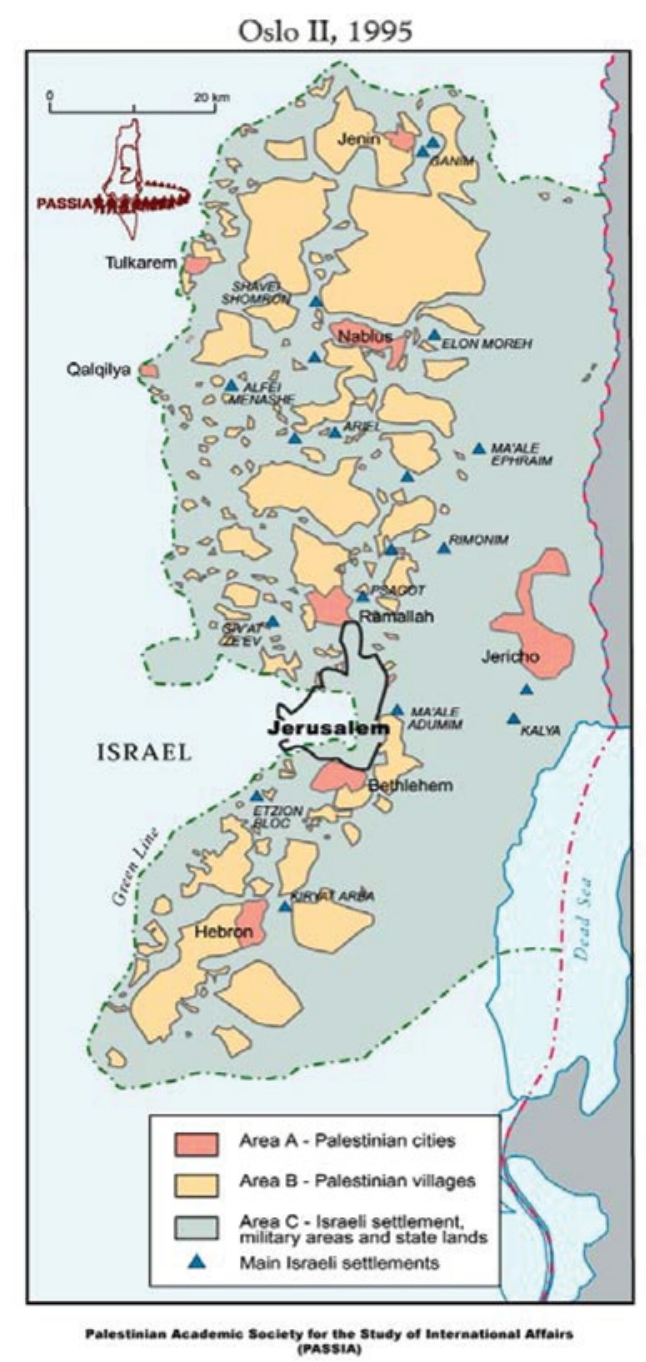

Map 1 : Areas A, B and C, West Bank. PASSIA.

This parceling out process is accentuated by the construction of the Israeli wall and by the ongoing colonization [Trottier, 2007 ; Latte-Abdallah and Parizot 2011 ; Bontemps and Signoles, 2012]. In this article, we will focus on Area $\mathrm{C}$ which represents the major part of the WB but also the major water resources ${ }^{3}$. Since the creation of the PA in 1994, donors have focused on PA's empowerment. In the water sector, they focus on the Palestinian Water Authority

1. There are 2.4 million Palestinians in WB, 180000 of whom live in Area C. B'Tselem, Acting the Landlord: Israeli's Policy in Area C, the West Bank, June 2013, p.12.

2. Contrary to the legend of the map and as stated above, Area C is not only "Israeli settlement, military areas and state lands". According to the Interim Agreement Area C is "areas of the West Bank outside Areas A and B"; it also includes Palestinian villages, the Jordan Valley, nature reserves and national parks, lands located between the Separation Barrier and the Green Land. According to B'Tselem $70 \%$ of Area C is off-limits to Palestinian use (http:// www.btselem.org/area_c/taking_over_land).

All the maps used in this article have been created by the NGO Palestinian Academic Society for the Study of International Affairs: http://www.passia. org/maps.htm.

3. For the purpose of this article, we make uniform areas but, of course, they are not: there are differences in the water resources available, the modalities of distribution, the prices, etc.
(PWA) and domestic water [Trottier, 1999 ; Le More, 2008: 133-134; Fustec, 2014a]. For a few years, the interest of donors seems to evolve towards Area $\mathrm{C}$ and agricultural issues. The water crisis in the Occupied Palestinians Territory (OPT) is multiform: it concerns water access, water treatment, water management, etc. It is generally accepted that the water crisis is a ratio between a quantity of water and a number of inhabitants. This definition does not take into account social, political and territorial dimensions of water issues [Linton, 2010 ; Julien, 2012]. Researchers have demonstrated the socio-political construction of the water crisis in the Israeli-Palestinian space [Alatout, 2008, 2009 ; Trottier, 2008]. In 2010, the WB and Gaza Strip were the $10^{\text {th }}$ entity receiving official development assistance per capita $^{4}$. The situation described above is largely explained by the Oslo Agreements that were initially scheduled for a transitional period of five years. In this context, how do donors participate to the water crises in the OPT?

Science and technology studies have demonstrated the socio-political construction of knowledge and the processes of co-construction of the social and natural order [Latour, 1984, 2005 ; Jasanoff, 2004]. Knowledge is situated [Haraway, 1988]. Nevertheless some knowledge or ideas about environment become universal truths or "environmental orthodoxies" [Forsyth, 2003]. These orthodoxies are generally produced at the international level by Northern actors. Political ecologists have studied the socio-political impacts of these orthodoxies in developing countries [Leach and Mearns, 1996 ; Goldman and Turner, 2011]. Development actors tend to depoliticize their policies but Ferguson [1990] has demonstrated that development projects, presented as technical, are intrinsically political. We will study the discourses and projects of donors concerning water issues in the WB and their impacts on socio-political organizations and on nature. This article is mainly based on our doctoral research ${ }^{5}$. Our fieldwork took place during the years 2011 and 2012.

This article studies the politics and policies of donors. Then, it analyzes the recent changes in water policies and the representations of water and land that this implies. It concludes on its impacts on the socio-political organizations and on natural resources.

\section{DONORS' FOCUS ON STATE-BUILDING AND URBAN WATER}

\section{II.1. The Oslo Agreements: a framework for donors' policies}

External actors play an important role in the Israeli-Palestinian conflict in general and in the water sector in particular. The first factor explaining donors' policy is the frame resulting from the Oslo Agreements. As stated above, these agreements were supposed to be transitional, for a period of five years, before the creation of the Palestinian State. Even if the Palestinian State was recognized as an observer non-member State by the United Nations on $29^{\text {th }}$ November 2012, nothing has really changed on the ground and the Oslo Agreements are still effective. These agreements plan a progressive settlement of the conflict, leaving delicate issues for the future [Roberts, 2005: 17]. Consequently,

\footnotetext{
4. The World Bank: http://data.worldbank.org/indicator/DT.ODA.ODAT.PC.ZS

5. Fustec K., 2014, Processus multi-échelle, enjeux environnementaux et construction étatique. Le cas de l'Autorité palestinienne, des politiques de gestion de l'eau et du changement climatique, Thèse de doctorat, Géographie, Université Paul Valéry, Montpellier, 584 p. (https://tel.archives-ouvertes.fr/ tel-01138056/file/2014_FUSTEC_arch.pdf)
} 
refugees, Jerusalem status, colonization, borders and water ${ }^{6}$ problematics remain unresolved. Water is the subject of discussions between the PA, the Israeli government and the donors. The impacts of the Oslo Agreements on water rights have been studied largely [Trottier, 1999 ; Daibes, 2003]. Since Oslo Agreements, water policies are shaped by Israeli domination and donors' omnipresence. The agreement of $4^{\text {th }}$ May 1994 plans that colonies and wells are excluded from the jurisdiction of the PA, constrains the power of the $\mathrm{PA}^{7}$ and makes the PA responsible for the unpaid water delivered by Mekorot (the Israeli national company) to Palestinians. The Protocol concerning Civil Affairs established the Joint Water Committee (JWC) ${ }^{8}$. Decisions about water are submitted to the approval of the JWC. The Israelis de facto have a veto on water decisions: to dig a well, to build a treatment plant, etc. The agreements fix the quantities of water for each part and, since 1995, they have not been renegotiated. In Area $\mathrm{C}$, under Israeli control, decisions concerning planning and water management have to go through the JWC but also through the civil Israeli administration. The Palestinian demands have very small chances to succeed while Area $\mathrm{C}$ represents an important potential of water resources (ground water with mountain aquifers and surface water with the Jordan, see map 2). To sum up, the Oslo Agreements are maintaining the OPT in an unequal situation.

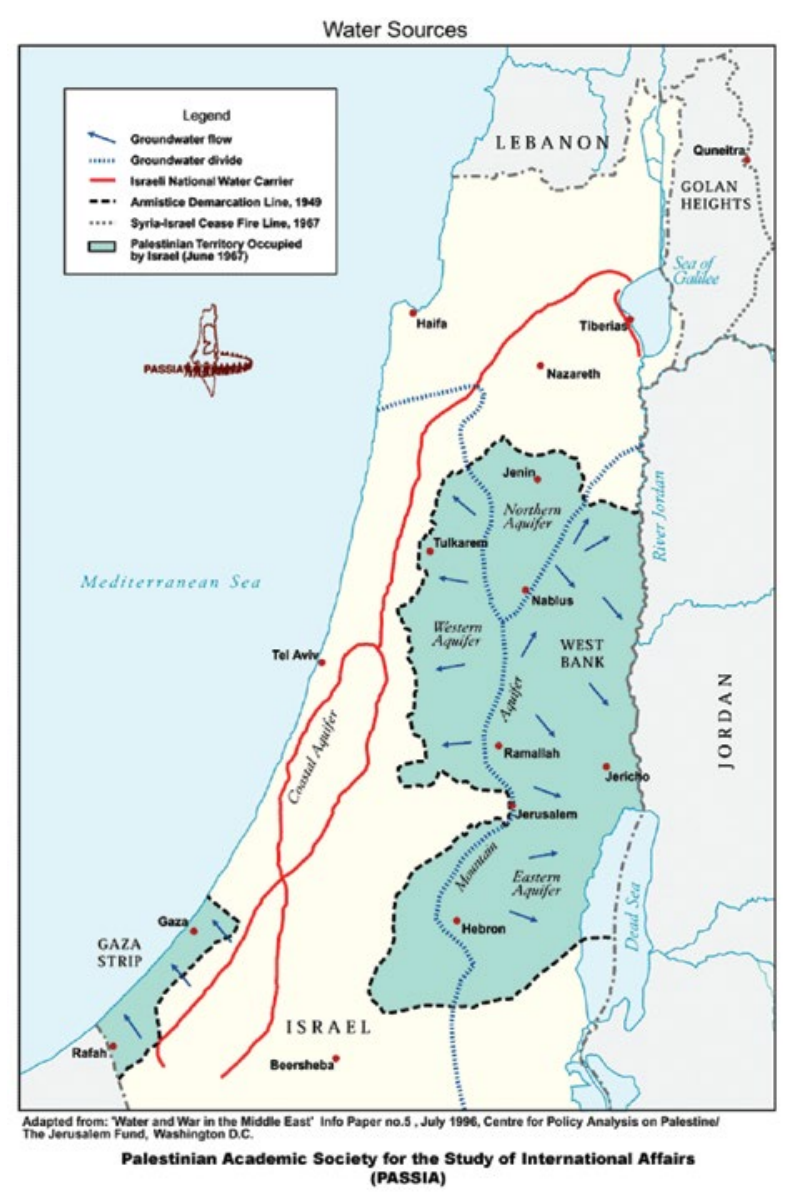

Map 2 : Water sources, PASSIA.

\footnotetext{
6. Oslo Agreement, 1995, Annex III, art. 40.1.

7. Article VII.

8. The JWC consists of half Israeli government representatives and half Palestinian government representatives.
}

On the first hand, the power of the PA is constrained by the Israeli government but, on the other hand, local Palestinian actors also control water at their level: "The PA is now facing competition for the control of water access and water use from several actors. Local actors control most of the 18\% of the West Bank water granted to the Palestinians by the Taba Agreement whereas Israel controls most of the rest" [Trottier, 1999: 72]. Signoles [2010] explains that the PA has difficulties to control municipalities. They defend their interests and agendas and they conserve some autonomy.

The Oslo Agreements are the basis of the dynamics occurring in the water sector since the 1990s. The JWC, the territorial division and the colonization are the major factors explaining the unequal relations between the Israeli government and the PA. Donors' actions in the water sector follow the same frame and even participate to its consolidation. We will see that donors want to promote peace and Palestinian state-building. They claim that the application and the respect of the Oslo Agreements are the conditions sine qua non for peace and state-building. As they focus on the PA, they concentrate on Area A and on distribution networks in urban areas.

\section{II.2. Linking water and state-building}

In the OPT, donors tie water issues to the aims of state and peace-building. They develop a functionalist or neo-liberal approach of peace [Bouillon, 2004 ; Aggestam and Sundell-Eklund, 2014]. In this paradigm, economic growth is supposed to bring peace. In a post-conflict context, peace-building means creating stability, restoring institutions and improving the socio-economic situation [Barnett et al., 2007: 49]. These representations are based on the idea that economic growth, the empowerment of the governmental institutions and peace operate together. These ideas are relying mainly on the European cooperation on technical issues such as coal and steel. The main problem here is that this approach undermines the political dimensions of these problematics, described as technical. Aggestam and Sundell-Eklund [2014] have demonstrated that the Oslo Agreements depoliticize the conflict and underestimate the asymmetric relations between the Israeli Authorities and the Palestinian Authorities.

Donors' aim is to support the PA, future State of Palestine. In this context, water is described as a cooperative goods and a pillar of state-building. For instance, a water project was proposed in the "State and Peace-building" programme of the World Bank (WB) ${ }^{9}$. Water projects are described as technical issues and therefore suitable for cooperation ${ }^{10}$.

Let's now focus on French donors in order to understand how the links between water and state-building influence the majority of the donors. French cooperation brings the Service de Cooperation et d'Action Culturelle, the Agence Française de Développement (AFD), decentralized cooperation actors (municipalities, agences de l'eau, etc.), and Non-Governmental Organizations (NGOs) together ${ }^{11}$. All actors do not follow the same aims but globally, their action

\footnotetext{
9. The World Bank, West Bank and Gaza - State and peace-building Fund: project proposal - water supply and sanitation improvements for West Bethlehem villages, Washington DC, June, 24, 2011.

10. It can be large projects like the Red-Dead canal but also smaller ones like the "Good Water Neighbors » project of the NGO Friends of the Earth Middle East.

11. France gave 43 million euros to the OPT in 2013, http://diplomatie.gouv $\mathrm{fr} /$ fr/pays-zones-geo/israel-territoires-palestiniens/la-france-et -les-territoires.
} 
tends to be centralized by the French consulate. The main actor, financially and politically, is AFD. An important difference between those actors is the distinction between development assistance and humanitarian aid. In the Palestinian context, the lengthening of the conflict tends to institutionalize humanitarian action. Humanitarian actors focus more on emergency situations, on Area $\mathrm{C}$ and on small projects (truck water distribution, sanitation kits distribution, etc.). Development actors focus mainly on Area A, on the empowerment of the PA and on large infrastructure projects (such as distribution networks). The vast majority of actors claims that the two-state solution is the unique solution to the conflict. If development actors associate water infrastructure projects to the empowerment of the PA, humanitarian actors explain their strategy toward Area $\mathrm{C}$ as a support to keep Palestinians on their lands and, thus, to preserve the two-state solution.

\section{II.3. Water and development: focusing on drinking and urban water}

Donors fund projects, institutional reforms, information campaigns, etc. Fluxes of money, knowledge and power are circulating. Donors cannot be considered as a uniform actor. Nevertheless, there are similarities in their policies about water. Since Dublin conference (1992), water and sanitation are environmental and development issues at the global scale. After Rio Summit (1992), bilateral aid as well as multilateral aid have increased [Hicks et al., 2010: 31]. In 2002, the Millennium Development Goals (MDG) were adopted by the United Nations members. Target 7 refers to water problematics ${ }^{12}$ and focuses on drinking water and therefore urban water. The goal is to "halve, by 2015, the proportion of the population without sustainable access to safe drinking water and basic sanitation" ${ }^{3}$. Even if some researchers like Attaran [2005] have pointed the lacks of the MDG indicators, development policies are still aiming at these goals. Drinking water access through the network is generally presented as the only solution. Nevertheless, we can question the naturalization of this idea. The objective of complete access to the water network has been criticized by researchers [Petitet and Schneier-Madanes, 2005 ; Ferré and, Scherrer, 2010 ; Petitet, 2011]. Petitet [2011] explains that this idea was developed and promoted in a specific context ( $19^{\text {th }}$ century and industrialization in Northern countries). If a network is not maintained, it can be dangerous. Is the necessity of the water network a question of human density, of human right or a political construct? Other solutions exist: more flexible, less expensive and less centralized. According to Petitet [2011], water networks and these other solutions may be complementary.

Nevertheless, in the WB, donors focus on urban water and on networks ${ }^{14}$. They consider very little agriculture and community-based management of natural resources. A striking example is the report of the WB published in $2009^{15}$. In this

\footnotetext{
12. United Nations: http://www.un.org.fr/milleniumgoals/environ.shtml.

13. United Nations: http://www.un.org/millenniumgoals/environ.shtml.

14. In the West Bank, the estimated number of people without access to the water network differs from a source to another. According to Oxfam (Oxfam, The ADCR 2011: Human Deprivation under Occupation, United Nations Development Programme Arab Development Challenges Report Background Paper, 2011/12), $82 \%$ of the household have access to the water network in the WB but only $2 \%$ in Area C.

15. World Bank, West Bank and Gaza, Assessment of restrictions on Palestinian Water sector development, Report No. 47657, April 2009.

For a deeper understanding of the role of the WB in water development policies see Goldman (2007).
}

report, agriculture is not represented in the global scheme of water they propose whereas it represents more than $70 \%$ of water withdrawal [Fustec, 2014a]. Community-based regimes are predominant in rural areas [Trottier, 1999, 2007, 2013a]. Nonetheless, in this report, they are totally erased and likened to private regimes.

In this first part, we demonstrated that the Oslo Agreements, the aim of state-building and the objective of full access to drinking water networks determine the policies of donors in the OPT. There are other explanations to donors' action such as the scientific formation of water experts [Fustec and Trottier, 2016], diplomatic interests, the acquaintanceship between experts and elites [Fustec, 2014a], etc. We do not document these issues here but they should be kept in mind. For a few years, donors in the OPT seem to orient their projects towards Area $\mathrm{C}$ and agriculture ${ }^{16}$.

\section{RECENT CHANGES: AREA C AND RURAL WATER}

\section{III.1. Area C and state-building}

The Civil Israeli administration is responsible for Area $\mathrm{C}$; it refers to the Coordinator of Government activities in the Territories (COGAT) which reports to the Ministry of Defense. The Israeli Authorities deliver only a few permits. According to B'Tselem ${ }^{17}$, between 2000 and 2012, 3150 permit demands have been requested by Palestinians and only $5.6 \%$ have been approved. All donors do not follow this procedure, some of them do not ask for permits before implementing a project. Generally, in this case, the Israeli Authorities deliver a stop work order and then a demolition order (if the first order was not followed).

For a few years, donors began to focus on area C. According to B'Tselem, the European Union (EU) and the member-states began to invest in Area $\mathrm{C}$ in 2009, working on master plans for Palestinian villages ${ }^{18}$. On the contrary to humanitarian actors, development actors' interest for Area $\mathrm{C}$ is new. According to an employee of the French consulate in Jerusalem ${ }^{19}$, donors prefer to work on Area A because they do not have to go through the Israeli permit system and so projects' implementation is easier. However, there is a growing interest for this territory. In 2010, an EU interest group for Area $\mathrm{C}$ was set up by the EU Representative in East Jerusalem. In 2011, the EU published a report "Area C and Palestinian state building", illustrating this new focus. The PA is also interested in Area $\mathrm{C}$ and claims that it belongs to the Palestinian territory but it does not really integrate it to its national plans ${ }^{20}$. In fact, the PA seems more interested in international negotiations [Le More, 2008] or in searching for legitimacy at the international level [Fustec, 2014b] than in local development.

In their discourses, donors explain their interest for Area $\mathrm{C}$ arguing that the safety of the two-state solution also relies on this territory: "the Palestinian state-building project is in effect partly limited to the fragmentation and isolated 'islands' of Areas $A$ and $B$ in the 'ocean' of the contiguous

\footnotetext{
16. For a global understanding of donors' water policies at the international level since 1945 see Fernandez (2014).

17. B'Tselem, Acting the Landlord: Israel's Policy in Area C, the West Bank, June 2013.

18. B'Tselem, Acting the Landlord: Israel's Policy in Area C, the West Bank, June 2013, p.18.

19. Interview, 26/04/2012, Jerusalem.

20. EU, Area C and Palestinian State Building, July 2011, p.3
} 
Area $C^{\prime 21}$. The EU explains that colonization and access restrictions challenge the two-state solution. Access to natural resources and to lands is described as necessary for demographic and economic development ${ }^{22}$. The EU notices the lack of development projects in Area $\mathrm{C}$ and recommends a better articulation between aid, state-building and territorial divisions: "[...] the EU will have to address in a more consistent manner the disconnection between qualitative state-building (massive aid input), quantitative territorial fragmentation (obstacles to goal orientation) and the expected output of an independent, democratic, contiguous, sovereign and viable State of Palestine (the overarching goal) '"23. The absence of Palestinian sovereignty on Area $\mathrm{C}$ is also described as an obstacle for sustainable economic development. Other donors also express their will to integrate Area $\mathrm{C}$ in their development strategies. A report published by the $\mathrm{AFD}^{24}$ explains that, according to the strategy of the PA, the AFD has oriented its action towards Area $\mathrm{C}$ since 2008. The $\mathrm{PA}^{25}$ also explains its interest in Area $\mathrm{C}$ in accordance with the two-state solution. The main argument here is that the territorial fragmentation compromises the continuity of the territory and, therefore, the state-building process. Concretely, these discourses find only few applications on the ground.

Are these discourses real political support? Although Area $\mathrm{C}$ should be considered as entirely part of the Palestinian territory, donors' policy must be studied in detail. Faggi [1990] explains that when donors implement a project, they claim to follow an objective but they really follow another strategy. The logic is productive like the development of agriculture or strategic like the control of territory and population. We do not consider that all projects have a hidden side but, nonetheless water projects are generally presented as technical whereas they have political dimensions. The notions of "productive logic" and "strategic logic" are helpful to study these dimensions. Here the productive logic is the development of Area $\mathrm{C}$ and agriculture. The strategic logic is to increase the power of the PA, the presence of donors on the field and their legitimacy in international negotiations ${ }^{26}$. We can raise here the questions of donors' participation to the domination system. We could also ask the same question about PA's elites [Fustec, 2014a]. In Area C, donors finance projects that are generally demolished (if they do not ask for permits). Then, they rebuild. Isn't it a vicious circle? In the water sector, they participate in the rehabilitation or extension of water networks supplied by Mekorot [Fustec, 2014a] and in the case of agricultural development, the example of $\mathrm{Al}$ Auja ${ }^{27}$ shows that Mekorot can be the main supplier for irrigation [Trottier, 2013a, 2013b]. As demonstrated before by Brynen [2000], Keating, Le More and Lowie [2005], Le More [2008] donors participate in the institutionalization of the status quo and its reinforcement.

The causal relation between the two-state solution and the increasing participation of donors in Area $\mathrm{C}$ must be questioned. As we will see below, other interests like irrigated and

\footnotetext{
${ }^{21 .}$ EU, Ibid, p. 9

22. EU, Ibid, p. 1

23. EU, Ibid, p. 9

24. WB: http://www.worldbank.org/en/news/press-release/2013/10/07/palestinians-access-area-c-economic-recovery-sustainable-growth.vary Sivalingam, Roger Schrader \& Tarik Carney, SciencePo, Master of Public Affairs, May 17, 2013.

25. PNA, Moving toward the status quo: safeguarding the two-state solution, PNA report to the Ad Hoc Liaison Committee, September, 23rd 2012, New York, USA, p.10.

26. For instance, Le More (2008) has demonstrated that there is a competition between donors to be a key player in international negotiations.

27. Al Auja is situated in the Jordan Valley, about 10 kilometers North Jericho.
}

export agriculture's development may be at stake and modify socio-political organizations as well as natural resources.

\section{III.2. Area C: an opportunity for irrigated and export agriculture?}

We can link donor's interest for Area C to Kerry's plan for the development of high added-value agriculture. Area $\mathrm{C}$ appears to be, if not virgin, a high potential territory, a new horizon for investment and a source of income. According to EWASH $^{28}, 63 \%$ of the WB agricultural lands are situated in Area C. In 2012, the EU described Area C as the "main land reserve" 29 of the future Palestinian state. Donors generally attribute to this territory an instrumental value.

Kerry's initiative promotes the economic development of the $\mathrm{OPT}^{30}$. For 2014-2016, 4 billion of dollars, coming partly from private funds, were planned to be invested in eight strategic sectors: agriculture, construction, tourism, communication and information technologies, small industries, construction materials, energy and water. The first objective is the economic growth through private investments. For agriculture, the plan wants to transform the production: from low fertilizers, low productivity and rain-fed agriculture to high productivity and high added-value agriculture. Manon Müller [2013] explains that this paradigm considers agriculture solely through its contribution to the Growth Domestic Product (GDP). Here, each cubic meter of water used for agriculture is considered for its participation to the GDP. Manon Müller describes the context as a "paradigm of GDP per cubic meter of water" [2013: 69]. Kerry's plan wants to reduce the number of exploitations and, consequently, to increase their surface. These changes require an augmentation of water resources available for agriculture. To develop agriculture, water supply has to increase. Until now, in the OPT, the vast majority of the cultures are rain-fed (about $94 \%)^{31}$. Rain-fed agriculture (wheat, barley, etc.) is not generating high incomes. On the contrary, irrigated cultures (oranges, tomatoes, etc.) generates high added value. An augmentation of the irrigated areas augments the productivity.

Trottier [2013a] explains that the first investment in the agricultural sector is Al Auja dam. It was supposed to supply water for irrigation. It was built by the Ministry of agriculture and funded mainly by the Islamic Bank. Since the opening ceremony by S. Fayyad ${ }^{32}$ on April 2012, this dam, with a capacity of 700000 cubic meters, has not been functioning. Trottier [2013a] demonstrates the arrival of new actors -agro-businesses- in 2008 in Al Auja village. Trottier [2012b] explains that the agricultural sector was very risky before the financial crisis of 2008. After that, new actors began to focus on agriculture, but not rain-fed agriculture, irrigated agriculture. This process, associated with land grab-

28. According to EWASH, Water for agriculture in the West Bank, Fact Sheet $\mathrm{n}^{\circ} 14$, March 2013, http://www.ewash.org/files/library/WB\%20 factsheet $\% 20$ fianl $\% 20$ march $\% 209 \% 5$ B $1 \% 5$ D.pdf.

29. Press Release, $3166^{\text {th }}$ Council meeting, Foreign Affairs, Brussels, 14 May 2012, President Catherine Ashton, High Representative of the Union for Foreign Affairs and Security Policy.

30. The discussions for peace under Kerry's initiative began in July 2013. The dead-line for the negotiations was on $29^{\text {th }}$ April 2014 but no agreement has been found. As explained in section 2.2, the main idea of this plan is also that economic growth is a pre-requisite for peace.

31. EWASH, Water for agriculture in the West Bank, Fact Sheet $n^{\circ} 14$, March 2013, http://www.ewash.org/files/library/WB\%20factsheet $\% 20$ fianl\%20 march $\% 209 \% 5$ B $1 \% 5$ D.pdf and Brown and Crawfords report (2009), only $6,8 \%$ of the cultivated land are irrigated.

32. Prime-minister at this time. 
bing, is already largely visible elsewhere in the world. In this context, water is a means of production. It needs to be secured so as to ensure incomes.

Trottier [2013a, 2013b] shows that, in the case of Al Auja, the agro-businesses are connected to the network of Mekorot. The case studied by Trottier informs of the changes in power relations linked to changes in water management: from small farmers to agro-businesses. Trottier [2013a] analyzes the disappearance of Al Auja spring and its consequences. The origin of the drying up of the spring is not clearly identified by hydrologists but the inhabitants consider that the wells of the Jerusalem Water Undertaken (JWU) are responsible. The water produced by the JWU is mainly used for domestic uses of the urban population in Ramallah, center of the power of the PA. Trottier explains that after this drying up, people were not able to cultivate bananas as they usually did. Some farmers sold their lands to agro-businesses who began to cultivate products for export. This contractual agriculture matches the donors' strategic orientations. We think this is not a coincidence and this should be studied on a longer period.

Here, irrigated agriculture modifies power relations. It benefits the agro-businesses that are generally an external and urban elite. Manon Müller [2013] shows how the construction of King Abdallah's canal in Jordan in the 1950's has modified power relations. Before its construction, water rights were associated with land rights. After, water rights were confiscated to the benefit of the State. The change from rain-fed agriculture to irrigated agriculture has favored the urban elites to the detriment of traditional rural elites. Changes concern both society and nature. In the OPT, the increasing interest of donors for Area $\mathrm{C}$ and for irrigated agriculture through the construction of Al Auja dam or projects of treatment plants would necessarily affect power relations but also water resources.

\section{CONCLUSIONS: OBFUSCATING A PART OF THE BIO-PHYSICAL AND SOCIO-POLITICAL REALITY TO CONSTRUCT THE DESIRED ORDER?}

Donors develop a depoliticized approach of development and water issues but, as we demonstrated earlier, development projects are highly political. Donors' policies favor some territories (Area A) and social groups (urban elite and PA).

This figure shows how a part of the social and natural reality is made invisible. Donors have a particular representation of water, territory, State, etc. This produces an imagined reality or develops a reality that they want to construct. This is possible thanks to the coalition of interests formed by some representatives of the Israeli government, PA and donors. Donors justify their policies in accordance to the two-state solution. Their representation of the State and the territory is a traditional definition in International Relations of the power of the State on the territory including possession, authority and control. The interest for Area $\mathrm{C}$ coincides with the support to export agriculture. These changes represent an evolution in the representations of water: a "conversion of water from an artisanal to an industrial product" [Bakker, 2004 : 42]. Donors participate to the co-construction of nature and society. They hide a part of the reality and they build the social and natural order desired. Finally, they participate in the construction of a "governmental entity above the ground": the PA [Fustec, 2014], on Area A, where urban concentration is high and which represents only $18 \%$ of the territory. Area $\mathrm{C}$, land and water have strategic value. Even if donors act in good faith, these depoliticized representations do not take into account the reality on the ground and the socio-political impacts of the projects. The policies of water in Area C may predict important changes like intensive agriculture or migration from rural areas to urban centers.

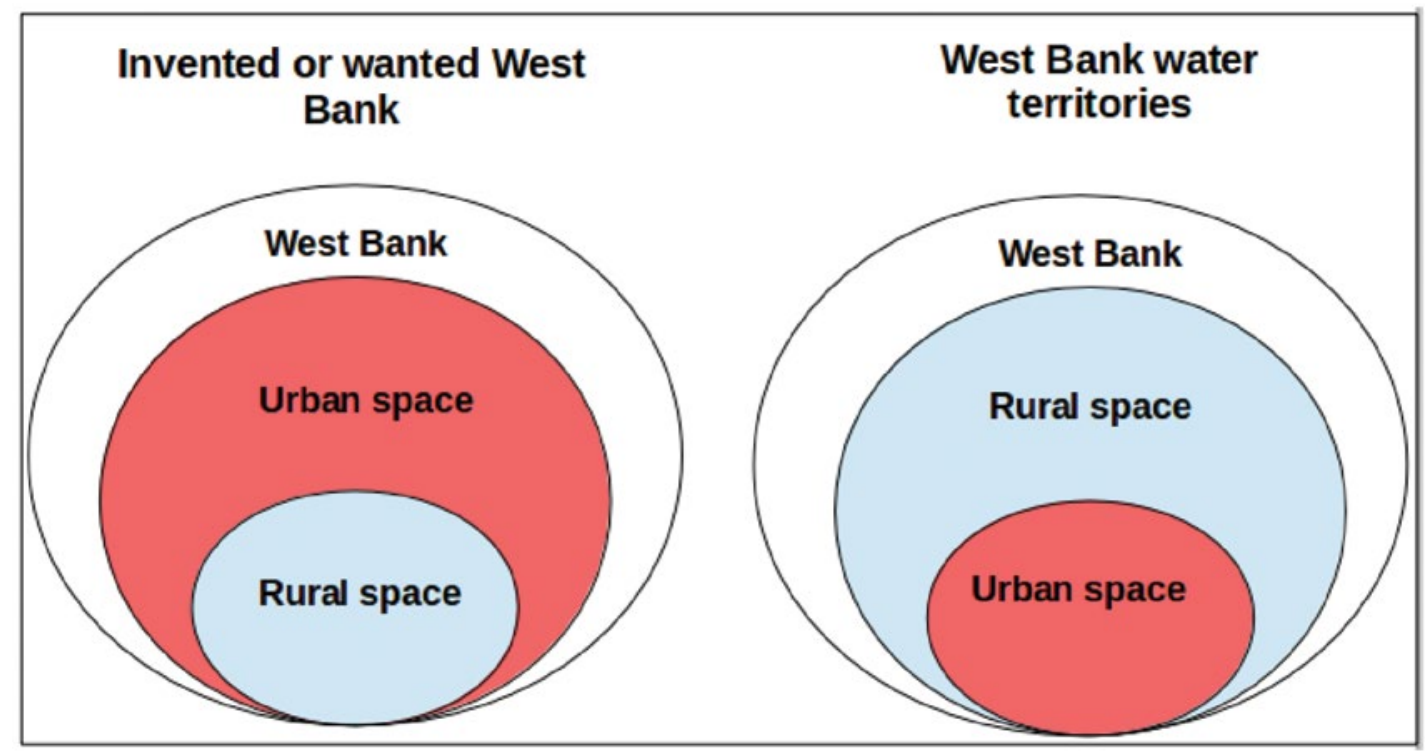

Figure 1 : From the invented or wanted West Bank to the West Bank water territories, K. Fustec.

\section{REFERENCES}

AgGestam Et Sundell-EkLund (2014) - Situating water in peacebuilding: revisiting the Middle East peace process. Water International, 39(1), 10-22.
Alatout S. (2008) - 'State' of scarcity: water, space, and identity politics in Israel. Environment and Planning D: Society and Space, 26(6), 959-982.

Alatout S. (2009) - Bringing abundance back into environmental politics: Constructing a Zionist Network of Abundance, 
Immigration, and Colonization, 1918-1948. Social Studies of Science, 39(3), 363-394.

AtTARAN A. (2005) - An immeasurable crisis? A criticism of the Millennium Development Goals and why they cannot be measured. PLoS Med, 2(10), 955-961.

BAKKeR K.J. (2004) - An Uncooperative Commodity: Privatizing Water in England and Wales. Oxford /New York, Oxford University Press.

Barnett M., Kim H., O’donnell M., Sitea L. (2007) Peacebuilding: What Is in a Name?. Global Governance, 13 (1), 35-58.

Bontemps V., Signoles A. (2012) - Vivre sous occupation : quotidiens palestiniens. Paris, Gingko, 125 p.

Boulllon M.E. (2004) - The peace business: money and power in the Palestinian-Israeli conflict. London, I. B. Tauris, $247 \mathrm{p}$

BRYNEN R. (2000) - A very political economy: peacebuilding and foreign aid in the West Bank and Gaza. Washington, D.C., United States Institute of Peace Press, 296 p.

DAIBES F. (2003) - Water-related politics and their legal aspects A progressive approach for solving the water conflict, dans Daibes F. (dir.). Water in Palestine. Problems - Politics Prospects, Jerusalem, PASSIA, 5-50.

FAGGi P. (1990) - Les développements de l'irrigation dans la diagonale aride entre logique productive et logique stratégique. Revue de géographie de Lyon, 21-26.

FERE C., Scherrer F. (2010) - L'eau urbaine après le réseau? Villes du Liban et des nouveaux Länders allemands. Dans Schneier-Madanes G. (dir.). L'eau mondialisée. La gouvernance en question, Paris, La Découverte, 403-417.

FERguson J. (1990) - The Anti-politics Machine: 'Development', Depoliticization, and Bureaucratic Power in Lesotho. Cambridge, Cambridge University Press.

Fernandez S. (2014) - Gouverner les eaux depuis 1945 Internationalisation et intensification des flux de capitaux, de techniques et de modèles. In Pestre D. (Dir.). Le gouvernement des technosciences. Gouverner le progrès et ses dégâts depuis 1945 , Paris, Editions la Découverte, collection "Recherches", 203-230.

FoRsyth T. (2003) - Critical political ecology: the politics of environmental science. New York/London, Routledge, $336 \mathrm{p}$.

Fustec K. (2014) - Processus multi-échelle, enjeux environnementaux et construction étatique. Le cas de l'Autorité palestinienne, des politiques de gestion de l'eau et du changement climatique. Thèse de doctorat, Géographie, Université Paul Valéry, Montpellier, 584 p.

FusteC K. (2014) - L'Autorité palestinienne et le changement climatique comme problème public émergent. Critique Internationale, 1 (62), 109-123.

Fustec K., Trottier J. (2016) - La production des savoirs sur l'eau et le changement climatique : quelle place pour les Sciences Humaines et Sociales ? Le cas des projets de recherche financés par l'Union européenne. Sciences de la société, 62, 103-118.

GOLDMAN M. (2007) - How 'water for all!' policy became hegemonic: The power of the World Bank and its transnational policy networks. Geoforum, 38, 786-800.

Goldman M.J., TuRner M.D. (2011) - « Introduction ». Knowing nature. Conversations at the intersection of political ecology and science studies, Chicago, Chicago University Press, Goldman M.J., Nadasdy P., Turner M.D., (dirs.), 1-23.

HARAWAY D. (1988) - Situated knowledge: The science question in feminism and the privilege of partial perspective. Feminist studies, 14 (3), 575-599.

Hicks R.L., Parks B.C., Roberts J.T., Tierney M.J. (2010) Greening aid? Understanding the environmental impact of development assistance, New York/Oxford, Oxford University Press, 344 p.
JASANOFF S. (2004) - States of Knowledge. The Co-Production of Science and Social Order, Londres/New York, Routledge.

JuLien F. (2012) - La gestion intégrée des ressources en eau en Afrique subsaharienne paradigme occidental, pratiques africaines, Québec, Presses de 1'Université du Québec. 296 p.

Keating M., Le More M., Lowe R. (Dir.) (2005) - Aid, diplomacy and facts on the ground: the case of Palestine, London, Chatham House, 264 p.

LATOUR B. (1984) - Les microbes : guerre et paix ; suivi de Irréductions : guerre et paix, Paris A.M. Métailié.

LATOUR B. (2005) - La science en action : Introduction à la sociologie des sciences, Paris, La Découverte.

Latte-Abdallah S., Parizot C. (2011) - A l'ombre du mur : comprendre le régime d'occupation israélien. Dans Latte-Abdallah S., Parizot C. (dirs.). À l'ombre du mur: Israéliens et Palestiniens entre séparation et occupation, Arles, Actes sud/ MMSH, 15-48.

LinTon J. (2010) - What Is Water? The History of a Modern Abstraction, Vancouver, University of British Columbia Press, 352 p.

LeACH M., MEARns R. (1996) - Environmental change and policy. The lie of the land: challenging received wisdom on the African environment, Oxfords, James Currey, Leach M, Mearns R. (dirs.), 1-33.

Le More A., 2008 International Assistance to the Palestinians after Oslo: Political guilt, wasted money, London, Routledge, $239 \mathrm{p}$.

MANON Müller N. (2013) - Adjusting the lens of GDP per Cubic Meter of Water for Jordanian Agriculture. Autrepart, 2 (65), 67-83.

PARKs B.C., RoBerts J.T., TIERNEY M.L. (2010) - Greening aid? Understanding the environmental impact of development assistance,New York/Oxford, Oxford University Press, 344 p.

Roberts N. (2005) - Hard lessons from Oslo: foreign aid and the mistakes of the 1990s, dans Keating M., Le More M., Lowe R. (dir.). Aid, Diplomacy and Facts on the Ground: The Case of Palestine, London, Chatham House, 17-26.

Petitet S. (2011) - Eau, assainissement, énergie, déchets : vers une ville sans réseaux?. Métropolitiques, En Ligne.

Petitet S., Schneier-Madanes G. (2005) - Le "'modèle du réseau" face aux enjeux du développement durable. Economie \& Humanisme, 373, 19-24.

SignOles A. (2010) - "Quand le lieu compte". La réforme de la gestion de l'eau en Palestine : des configurations locales multiples. Géocarrefour, 2, 129-140.

Trottier J. (1999) - Hydropolitics in the West Bank and Gaza Strip, Jerusalem, PASSIA, 249 p.

Trottier J. (2007) - A wall, water and power: the Israeli "separation fence". Review of International Studies, 33, 105-127.

Trottier J. (2008) - Water crises: political construction or physical reality?. Contemporary Politics, 14 (2), 197 - 214.

Trottier J. (2012) - Water. The Routledge Handbook on the Israeli-Palestinian Conflict, Londres, Routledge. Peters J., Newman D. (dirs.), 145-153.

Trottier J. (2012) - L'avènement de la gestion intégrée des ressources en eau. Gestion de l'eau : approche territoriale et institutionnelle, Québec, Presses Universitaires du Québec. Lasserre F., Brun A. (Dirs.), 179-195.

TrotTiER J. (2013) - The social construction of water management at the intersection of international conflict: The case of $\mathrm{Al}$ Auja. La géopolitique de l'eau dans le monde arabe. Entre constantes et changements., Paris, L'Harmattan, Berthelot P. (dir.), p. 161-188.

Trottier J. (2013) - Terre et eau : deux solitudes ? Tentative d'intégration de deux littératures au développement parallèle - MSH-M.TV. Troisième journées doctorales du Pôle Foncier. 